Bisset, K. A. \& Pease, P. (1957). J. gen. Microbiol. 16, 382-384,

\title{
The Distribution of Flagella in Dividing Bacteria
}

\author{
By K. A. BISSET and PHYLLIS PEASE \\ Department of Bacteriology, University of Birmingham
}

SUMMARY: Two strains of bacteria which produced flagella when grown at $36^{\circ}$ but not at $44^{\circ}$ were examined; one was a strain of Salmonella typhimurium and the other of Proteus vulgaris. These organisms were grown on membranes for electron microscopy, being incubated at $36^{\circ}$ so that the parent bacteria of each microcolony possessed a normal quota of flagella, and then transferred to $44^{\circ}$ so that no more flagella were produced. In the microcolonies, after several divisions, it appeared that all these flagella were retained by the original parents, in accordance with the theory that bacteria of this type divide by budding from a growing-point at one pole.

The suggestion that the main growth of the cell envelopes in unicellular bacteria is from a growing-point at one pole was deduced from the behaviour of the flagella in dividing bacteria by Bisset (1951). It was found that in some cases one daughter had few flagella or none, whereas the other had a full complement; in other cases there appeared to be a progressive diminution in degree of development and age of the flagella from the point of division to the tip of one daughter, whereas once more the other daughter had all its flagella fully developed. At the putative growing-point the cell wall also appeared to be thinner and less well developed than over the remainder of the cell, and it could be shown to contain a relatively high concentration of basophilic material, presumably nucleoprotein.

Further evidence in support of this concept has been obtained from a variety of sources. Bergersen (1953) described the behaviour of similar growing points in Escherichia coli when their polarity of growth was so disturbed by cultivation in the presence of chloramphenicol that side-branches were produced instead of polar buds. Malek, Voskyova, Wolf \& Fiala (1954), by means of cinematography, confirmed the concept that bacteria of this type grow from one pole. The corollary, that multicellular septate bacteria grow from the points of junction of cell wall and cross-wall, i.e. from the tips of each component cell (Bisset, 1953) was confirmed by Tomesik (1956) with his elegant micro-serological technique.

However, it was suggested by Stocker (1956) and by Quadling \& Stocker (1956) that growth of the cell wall is diffuse and not localized at a growing point. These authors based their conclusions mainly upon the behaviour of a strain of Salmonella typhimurium which produced flagella at $37^{\circ}$ but not at $44^{\circ}$. Cultures were grown for a period at $37^{\circ}$ and then transferred to $44^{\circ}$ so that no more flagella were produced, although growth and division continued. When examined by Leifson's flagellar stain, the appearance of these cultures suggested that the flagella had not been retained by a small number of bacilli, representing those which already possessed them at the end of their period of growth 
at $37^{\circ}$ in accordance with the growing point theory, but that they were distributed throughout the culture.

In an attempt to resolve the discrepancy between these two sets of observations, it was decided to attempt to repeat those of Quadling \& Stocker upon Salmonella typhimurium by means of electron microscopy, which it was believed might provide a more reliable picture of the arrangement of the flagella than do the accretive staining methods. Similar observations were made upon a strain of Proteus vulgaris which behaved similarly in that it produced flagella when grown at $36^{\circ}$ but not at $44^{\circ}$.

\section{METHODS}

The strain of Salmonella typhimurium used in his own experiments was kindly supplied by Dr B. A. D. Stocker (Lister Institute, London). It was originally intended that a series of electron micrographs should be made upon material prepared by Drs Quadling and Stocker exactly in the same manner as they had done previously, but these cultures unfortunately proved to be mucilaginous and generally unsuitable for electron microscopy. Accordingly, it was decided to grow the bacteria upon collodion membranes over meat infusion agar according to the method of Hillier, Knaysi \& Baker (1948), and by inoculating with a very dilute suspension, to endeavour to obtain isolated microcolonies grown from one or a very small number of individuals in the inoculum. The inoculated membranes were incubated at $36^{\circ}$ for periods of from 1 to $4 \mathrm{hr}$. and then transferred to $44^{\circ}$ for further periods of one or more hours; they were then examined under the electron microscope.

These experiments were repeated with a freshly isolated strain of Proteus vulgaris, which was the most satisfactory of several strains of Gram-negative bacteria found to behave similarly with respect to the production of flagella at different temperatures. Other organisms proved liable to lose their flagella permanently, or their reactions were less-clear cut.

\section{RESULTS}

Whenever conditions were so arranged that discrete microcolonies were obtainable on the grids for examination, their appearance was entirely compatible with the growing-point theory of Bisset (1951). Only one, or a very small number of bacteria in each group appeared to possess flagella, and in these cases they had from six upwards; the majority had none at all. Thus it appeared as if during the initial period of incubation at $36^{\circ}$ the flagella had developed normally, and that on transfer to $44^{\circ}$ their development had ceased. The bacteria, however, had continued to divide at the higher temperature, and had grown from one pole, so that all the flagella remained with one daughter, the other being a naked bud.

These results are shown in Pl. 1, figs. 1-3, and explained in Figs. 1 and 2. Pl. 1, fig. 1, shows a portion of the circumference of a colony of Salmonella typhimurium grown from a fairly heavy inoculum which, after $3 \mathrm{hr}$. at $36^{\circ}$ and then $1 \mathrm{hr}$. at $44^{\circ}$, produced some colonies and some areas of confluent growth, 
it being assumed that the latter area developed from the confluence of several microcolonies. At the edge, where some flagella can be discerned, three bacilli only have flagella (arrows), the remainder have none. The unattached whips are presumably derived from the flagellate organisms of the inoculum. Pl. 1, figs. 2, 3 and $2 b, 3 b$ show microcolonies of Proteus vulgaris, grown from dilute inocula for $1 \mathrm{hr}$. at $36^{\circ}$ and $2 \mathrm{hr}$. at $44^{\circ}$. One cell in each case bears a full complement of flagella, the rest have none, although some have the short filaments known as 'fimbrae', In several hundred similar microcolonies, examined upon some twenty grids derived from a series of such experiments, exactly similar results were seen in every case. These observations are in accordance with the theory of bacterial growth from a growing point at one pole (Bisset, 1951). The reason for the discrepancy between these results and those of Quadling \& Stocker (1956) remains unexplained, despite the valued co-operation of these authors in the present investigation.

\section{REFERENCES}

Bergersen, F. J. (1953). Cytological changes induced in Bacterium coli by chloramphenicol. J. gen. Microbiol. 9, 353.

Brsset, K. A. (1951). The development of surface structures in dividing bacteria. J. gen. Microbiol. 5, 155.

Bisset, K. A. (1953). Bacterial cell envelopes. In Bacterial Cytology, Symp. 6th Congr. int. Microbiol. p. 9.

Hillier, J., KNaysi, G. \& Baker, R. F. (1948). New preparation techniques for the electron microscopy of bacteria. J. Bact. 56, 569.

Malek, I., Voskyová, L., Wolf, A. \& Fiala, J. (1954). Nerovnocennost bakterijních buněk při délení. Č́eskoslovenská Biol. 3, 135.

Quadling, C. \& STocker, B. A. D. (1956). An environmentally induced transition from the flagellated to the non-flagellated state in Salmonella: the fate of parental flagella at cell division. J. gen. Microbiol. 15, i.

Stocker, B. A. D. (1956). Bacterial flagella: morphology, constitution and inheritance. In Bacterial Anatomy; Symp. Soc. gen. Microbiol. 6, 19.

Tomcsik, J. (1956). Bacterial capsules and their relation to the cell wall. In Bacterial Anatomy; Symp. Soc. gen. Microbiol. 6, 41.

\section{EXPLANATION OF PLATE}

Plate 1

Fig. 1. Salmonella typhimurium. Grown for $3 \mathrm{hr}$. at $36^{\circ}$ then $1 \mathrm{hr}$. at $44^{\circ}$. Edge of colony; flagellate cells shown by arrows. Electron micrograph, metal shadowed; $\times 6000$.

Figs. 2, 3. Proteus vulgaris. Grown for $1 \mathrm{hr}$. at $36^{\circ}$ then $2 \mathrm{hr}$. at $44^{\circ}$. Microcolonies; one cell in each colony has numerous flagella; some of the remainder have 'fimbrae'. Electron micrograph, metal shadowed; $\times 8000$.

Figs. $2 b$ and $3 b$ are drawn from Pl. 1, figs. 2 and 3 respectively. They show microcolonies after incubation for $1 \mathrm{hr}$. at $36^{\circ}$, to permit development of flagella in the germinating inoculum, followed by $2 \mathrm{hr}$. at $44^{\circ}$, when no further flagella should have developed. In each case, only one cell has flagella. 
Journal of General Microbiology, Vol. 16, No. 2
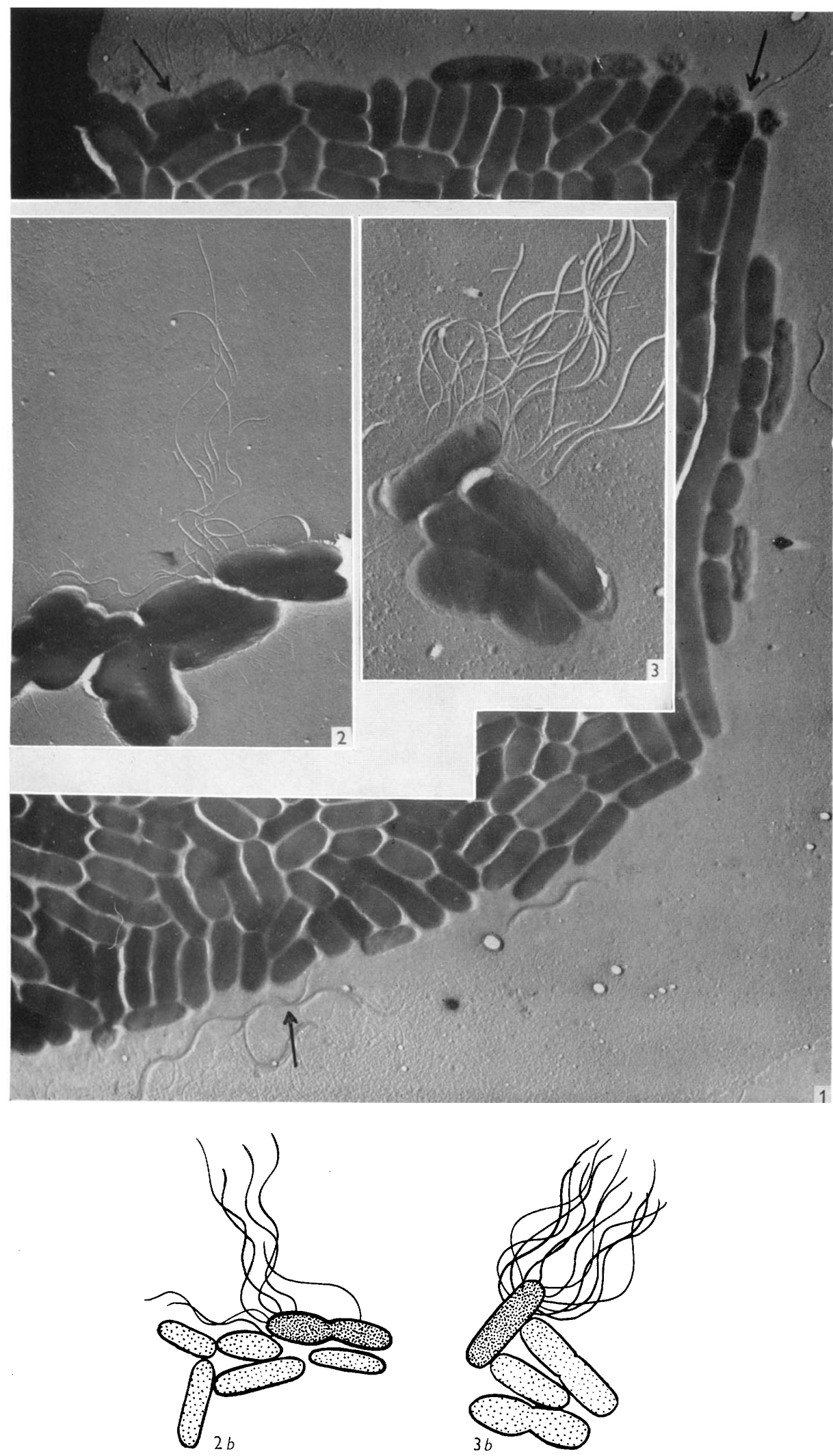

K. A. Bisset and P. Peash--The distribetion of Fiageila in mividing bacteria. Plate 1 